\title{
ONTYCZNE KONSEKWENCJE GRZECHU ADAMA W UJECCIU MAKSYMA WYZNAWCY
}

Pisząc o antropologii Maksyma Wyznawcy autorzy koncentrują się przede wszystkim na zagadnieniach przebóstwienia i obrazu Bożego w człowieku, często pomijając aspekt grzechu. Jeśli nawet jest on przywoływany, to raczej przy okazji sporu, czy Maksym uznawał teorię apokatastazy.

W niniejszym artykule chciałabym przede wszystkim ukazać, jakie konsekwencje grzechu pierwszego człowieka wskazuje Wyznawca. Jest to szczególnie interesujące, gdyż w odróżnieniu od teologów na Zachodzie Ojcowie wschodni zwracali uwagę, że ludzka natura została obciążona ontycznymi konsekwencjami grzechu Adama (a nie samą grzesznością) ${ }^{1}$. By ukazać te konsekwencje, muszę najpierw, choćby pokrótce, przedstawić sytuację, w jakiej znajdował się Adam w momencie stworzenia oraz sposób, w jaki Wyznawca rozumie rzeczywistość pierwszego upadku.

1. Obraz stanu przed grzechem. Poglądy Maksyma na temat bezgrzesznego bytowania Adama wyłaniają się z rozproszonych w różnych tekstach wzmianek $^{2}$. Przede wszystkim Wyznawca wskazuje, że

„stworzenie naszego praojca Adama dokonało się w sposób tajemniczy”3.

Wiele tajemnic kryje też samo życie w stanie rajskim. Maksym wydaje się rysować stan sprzed grzechu paralelnie do stanu niebieskiej szczęśliwości przewidzianej na końcu czasów dla człowieka. Badacze dyskutują, czy w myśli omawianego autora istnieją różnice $\mathrm{w}$ ujmowaniu kondycji człowieka w obu stanach $^{4}$. Nam, na potrzeby postawionego tematu, wystarczy wskazanie głów-

* Dr Karolina Kochańczyk-Bonińska - adiunkt w Katedrze Historii Wczesnochrześcijańskiej Literatury Greckiej w Instytucie Nauk Historycznych na Wydziale Nauk Historycznych i Społecznych Uniwersytetu Kard. Stefana Wyszyńskiego w Warszawie; e-mail: k.kochanczyk@uksw.edu.pl.

${ }^{1}$ Por. J.C. Larchet, Ancestral guilt according to St Maximus the Confessor: A bridge between Eastern and Western conceptions, „Sobornost” 20/1 (1998) 26-27.

${ }^{2}$ Por. L. Thunberg, Microcosm and Mediator. Theological anthropology of Maximus the Confessor, Lund 1965, 152-153.

${ }^{3}$ Maximus Confessor, Ambiguorum Liber 42, 26, PG 91, 1324D. Tłumaczenia fragmentów z dzieł Maksyma Wyznawcy, jeśli nie zaznaczono inaczej, zostały dokonane przez autorkę artykułu.

${ }^{4}$ Por. Thunberg, Microcosm and Mediator, s. 154; P. Sherwood, The Earlier Ambigua, Romae $1955,91$. 
nych elementów pierwotnego bytowania, które w swych pismach opisuje Maksym Wyznawca.

Adam przed upadkiem, na mocy stworzenia ( $\gamma \varepsilon \dot{v} v \varepsilon \sigma ı \varsigma)$, był bezgrzeszny 5 . Pierwszy człowiek jest dla Maksyma wzorem człowieka doskonałego, który cieszy się bezpośrednim oglądaniem Boga i posiada inny, subtelny rodzaj cielesności. Adam żyjąc w komunii z Bogiem miał możliwość doświadczania

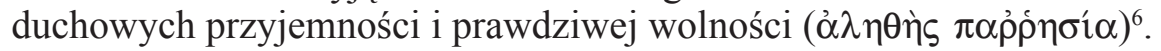

Wiele na temat poglądów Wyznawcy dowiadujemy się z jego eksplikacji fragmentu mowy Grzegorza z Nazjanzu, który o Adamie głosi, iż Bóg

„ustanowił go hodowcą nieśmiertelnych roślin, może Boskich myśli, tak prostych, jak doskonalszych, nagiego w prostocie obyczajów i skromności życia, bez jakiejkolwiek broni ochronnej lub zaczepnej, gdyż takim być przystało pierwszemu człowiekowi"?.

W Ambigua 45, w całości poświęconym wyjaśnieniu tych słów, Maksym nie tylko rozwija swoją teorię innego rodzaju ciała, które miał przed grzechem pierworodnym posiadać człowiek $^{8}$. Podkreśla też, iż przed grzechem Adam doświadczał harmonii w swojej cielesności. Co więcej, harmonia ta nie została zniszczona nawet po grzechu pierworodnym ${ }^{9}$. Nagość Adama nie polegała, jak chcieli orygeniści, na bezcielesności ${ }^{10}$. Adam był nagi, ponieważ nie był obciążony śmiertelnością i cierpiętliwością; nie musiał się okrywać ponieważ nie doświadczał ani pożądliwości, ani chłodu. Pierwszy człowiek trwał we wspólnocie miłości z Bogiem i niczego poza Nim nie potrzebował. Był nagi W swej prostocie ${ }^{11}$. W stanie rajskim Adam doświadczał wyłącznie poruszeń i przyjemności duchowych płynących ze wspólnoty z Bogiem ${ }^{12}$. Obce mu były wszelkie doznania zmysłowe ( $\pi \alpha ́ \theta o \imath)$ : nie tylko przyjemności, ale także odczuwanie bólu czy chłodu.

Według Adama G. Coopera Maksym zdecydowanie odrzuca związek między karą za grzech pierworodny, a cielesnym stworzeniem człowieka ${ }^{13}$. Bezgrzeszny Adam, choć cielesny, był wolny od tego, co czyniło jego ciało cięższym, śmiertelnym i nieodpornym ${ }^{14}$.

${ }^{5}$ Por. Maximus Confessor, Ambiguorum Liber 42, 7, PG 91, 1317A.

${ }^{6}$ Por. tenże, Epistula 32, PG 90, 625D.

${ }^{7}$ Gregorius Nazianzenus, Oratio 45, 8, PG 36, 632C, thum. zbiorowe: Św. Grzegorz z Nazjanzu, Mowy wybrane, Warszawa 1967, 534.

${ }^{8}$ Pozwolę sobie pominąc ten problem, gdyż wymaga on szerszej analizy, na którą nie ma w tym opracowaniu miejsca. Stanowisko swe Maksym przedstawia między innymi w Ambiguorum Liber 45, PG 91, 1353A-B.

${ }^{9}$ Por. Maximus Confessor, Ambiguorum Liber 45, PG 91, 1353A.

${ }^{10}$ Por. tamże, PG 91, 1353B.

${ }^{11}$ Por. tamże, PG 91, 1356D.

${ }^{12}$ Por. tenże, Quaestiones ad Thalassium 61, PG 90, 628A.

${ }^{13}$ Por. A.G. Cooper, The Body in St. Maximus the Confessor. Holy Flesh, Wholly Deified, Oxford 2005, 80 .

${ }^{14}$ Por. Maximus Confessor, Ambiguorum Liber 45, PG 91, 1353A-B. 
2. Grzech Adama. Skoro Adam trwał w doskonałej wspólnocie z Bogiem, to co spowodowało jego oddalenie? na czym polegał jego grzech? W swym nauczaniu Maksym nie jest oryginalny i wskazuje z jednej strony na niewłaściwe wykorzystanie wolności przez człowieka poprzez poddanie się zgubnym namiętnościom $(\dot{\varepsilon} \pi \imath \theta v \mu \mathfrak{i} \alpha \varsigma \tau \hat{\eta} \varsigma \alpha \dot{\alpha} \pi \dot{\alpha} \tau \uparrow)^{15}$, z drugiej strony na kuszenie przez diabła, aby poddać się przyjemnościom zmysłowym ${ }^{16}$. W obu przypadkach pojawia się charakterystyczny dla Maksyma wątek przyjemności.

„Naturalne rozumowanie Adama zostało wcześniej skażone przez porzucenie

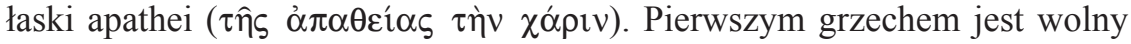
wybór zła zamiast dobra, drugim z niego wynikającym jest przejście natury ze stanu nieskażonego do zniszczenia"17.

Wydaje się, że to, co należy wyakcentować w poglądach Maksyma, to powiązanie grzechu pierworodnego ze zmysłowymi przyjemnościami skierowanymi w stronę świata doznań zmysłowych. Pogląd ten Claudio Moreschini wiąże $\mathrm{z}$ tradycją stoicką, nie tylko ze względu na podobieństwo terminologiczne, ale przede wszystkim ze względu na uznanie ich przez stoików za źródło $z{ }^{18}$, a przez Maksyma za przyczynę odwrócenia się od Boga ${ }^{19}$.

3. Konsekwencje grzechu. Już w samych opisach pierwszego upadku Maksym wskazuje na pewne jego konsekwencje dla ludzkiej natury. Choć Wyznawca kontynuuje tu część wspólnych Ojcom interpretacji, to jego nauczanie jest niewątpliwie oryginalne.

Wyznawca wskazuje, że po grzechu Adama zmienia się ludzki sposób istnienia. Zmianę tę opisuje Maksym rozpoczynając od wprowadzenia odrębnej terminologii określającej stworzenie pierwszego człowieka i początek istnienia kolejnych ludzi.

Przez stworzenie ( $\gamma \varepsilon \dot{v} v \sigma ı \varsigma)$ rozumie Maksym pierwsze ukształtowanie człowieka, poprzez które Adam otrzymał, bezpośrednio od Boga, doskonałą ludzką naturę ${ }^{20}$. Pierwszą konsekwencją grzechu jest zmiana sposobu przekazywania ludzkiej natury. Dla Maksyma, podobnie jak dla Grzegorza z Nys$\mathrm{sy}^{21}$, w pierwotnym planie Stwórcy duchowa natura miała być przekazywana w sposób pozaseksualny, rozmnażanie nie było powiązane z płciowością 22 .

${ }^{15}$ Tenże, Epistula 32, PG 90, 625D. Por. tenże, Questiones ad Thalassium 61, PG 90, 628A; tamże 42, PG 90, 405C.

${ }^{16}$ Por. tenże, Ambiguorum Liber 38, PG 91, 1301A.

${ }^{17}$ Tenże, Quaestiones ad Thalassium 42, PG 90, 405C.

${ }^{18}$ Por. C. Moreschini, Introductione, w: Massimo il Confessore, Ambigua. Problemi metafisici e teologici su testi di Gregorio di Nazianzo e Dionigi Areopagita, Milano 2003, 51-52.

${ }^{19}$ Szeroko pisze na ten temat w Quaestiones ad Thalassium 61, PG 90, 626D-645C.

${ }^{20}$ Por. Cooper, The Body in St. Maximus the Confessor, s. 216.

${ }^{21}$ Por. Gregorius Nyssenus, De creatione hominis 16, PG 44, 181C-D, thum. M. Przyszychowska: Grzegorz z Nyssy, O stworzeniu człowieka, ŹMT 39, Kraków 2006, 93.

${ }^{22}$ Por. Maximus Confessor, Ambiguorum Liber 41, PG 91, 1309A. 
Termin $\gamma \varepsilon ́ v \varepsilon \sigma ı \varsigma$ zostaje przez Maksyma odniesiony wyłącznie do stworzenia bezgrzesznego Adama oraz Wcielenia Chrystusa. Wszyscy ludzie, którzy narodzili się po upadku Adama otrzymują skażenie natury poprzez sposób prokreacji powiązany z przyjemnością zmysłową, który to sposób przekazywania życia został wprowadzony po upadku ${ }^{23}$. Zrodzenie ( $\left.\gamma^{\prime} v v \eta \sigma ı \varsigma\right)$ odnosi się do sposobu, w jaki człowiek przychodzi na świat po grzechu pierworodnym, a który to sposób rodzenia stał się podobny do zwierzęcego.

Wyznawca podkreśla, że Chrystus, jako Nowy Adam, narodził się inaczej niż pozostali ludzie. O zbawczym dziele Chrystusa wobec rozdarcia między $\gamma \hat{\varepsilon} v \varepsilon$ -

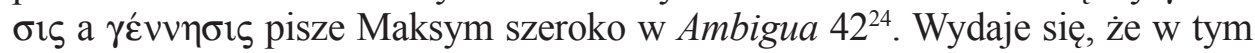
rozróżnieniu, a właściwie w cielesnym sposobie zrodzenia, zawiera Maksym wszystkie konsekwencje grzechu. Co więcej, sam sposób rodzenia jest równoznaczny z przekazywaniem następnym pokoleniom skażonej grzechem natury.

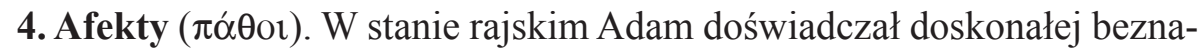
miętności, którą utracił na skutek upadku. Od tej pory ludzka natura poddana jest doznaniom zmysłowym. Fakt ten sam w sobie nie jest zły ani grzeszny. Wskazuje na to Maksym, gdy pisze, że Chrystus przyjął wypływającą z narodzin cierpiętliwośćc ${ }^{25}$. Niemniej, ścieżka dla zmysłowych pokus zostaje otwarta. Maksym Wyznawca łączy bowiem pierwszy upadek ze skłonnością woli do słabości i nieuporządkowanych przyjemności. Lars Thunberg wskazuje jak w Questiones ad Thalassium Wyznawca przeprowadza szczegółową analizę, czy $\pi \alpha ́$ ó same w sobie są czymś złym. Omawiane afekty to wymieniane przez stoików pożądanie, obawa, cierpienie i przyjemnośćc ${ }^{6}$. Nie zostały one stworzone na początku, ale dopiero po upadku wprowadzone zostały do nierozumnej części duszy ${ }^{27}$. Same w sobie jednak nie są złe, gdyż mogą być wykorzystywane w posłuszeństwie Chrystusowi, ale mogą też być słabym punktem, w którym jesteśmy kuszeni i doprowadzeni ostatecznie do śmierci ${ }^{28}$. Charakter afektów, skłonny bardziej do grzechu niż do cnoty, zostaje przekazany każdemu człowiekowi na mocy prawa rodzenia ( $\gamma \varepsilon \dot{\varepsilon} v \vee \eta \sigma i \varsigma)^{29}$.

${ }^{23}$ Jako pierwszy wśród Ojców Kościoła na związek między grzechem pierworodnym a płciowością wskazał Klemens Aleksandryjski, który zaprzecza, jakoby sam akt seksualny był zły i poza Bożym planem. Przyznaje jednak, że diabeł namówił Adama i Ewę do przedwczesnego skorzystania z przyjemności seksualnej. Choć sam akt seksualny nie jest według Klemensa grzeszny, to właśnie pragnienie i realizacja zmysłowej przyjemności poza wolą Boga stanowiło grzech pierwszych rodziców. Por. Clemens Alexandrinus, Stromata III 17, 103-104, PG 8, 1205B-1208B, thum. J. Niemirska-Pliszczyńska: Klemens Aleksandryjski, Kobierce zapisków filozoficznych dotyczacych prawdziwej wiedzy, I, Warszawa 1994, 290.

${ }^{24}$ Por. Maximus Confessor, Ambiguorum Liber 42, PG 91, 1316-1317A.

${ }^{25}$ Por. tamże 42, 6, PG 91, 1318A.

${ }^{26}$ Por. tenże, Quaestiones ad Thalassium 1, PG 90, 269A-C.

${ }^{27}$ Por. Thunberg, Microcosm and Mediator, s. 161.

${ }^{28}$ Por. Maximus Confessor, Quaestiones ad Thalassium 1, PG 90, 269A-C.

${ }^{29}$ Por. tamże 21, PG 90, 316D-317A. 
Grzech bowiem, podobnie jak w przypadku Adama, zaczyna się wtedy, gdy człowiek dąży do nieuporządkowanej przyjemności; przyjemności płynącej nie z kontemplacji Boga, ale z ukierunkowania na istoty zmysłowe. Taka przyjemność zostaje u Maksyma powiązana z bólem i śmiercią. Demetrios Batherellos mówi wręcz o obecnym u Wyznawcy zaklętym kręgu przyjemności i śmierci, z którego człowiek nie jest w stanie się sam wyzwolićc ${ }^{30}$. Już Hans Urs von Balthasar wskazywał, iż ta dialektyka przyjemności i bólu w powiązaniu z konsekwencjami grzechu Adama znajduje u Maksyma niespotykany nigdzie indziej wyraz ${ }^{31}$.

Zarówno cierpiętliwość, jak i druga konsekwencja grzechu, jaką jest śmier-

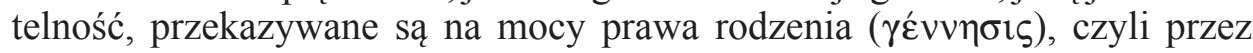
poczęcie powiązane ze zmysłową przyjemnością. To właśnie dlatego Maksym tak mocno podkreśla inny, dziewiczy, charakter narodzin ( $\gamma \varepsilon \dot{v \varepsilon} \sigma ı \varsigma)$ Chrystusa.

„Rzeczywiście [Chrystus], przez prawo współuniżenia, otrzymał ten rodzaj narodzin, które miał Adam przed upadkiem. Zgodnie z naturą otrzymał przez tchnienie bezgrzeszność, ale nie zyskał niezniszczalności. Jednocześnie, przez swoje dobrowolne uniżenie, przyjął, zgodnie z naturą, narodziny podlegające cierpieniom. Nie przyjął zaś skażenia grzechem i stał się nowym Adamem, otrzymując to samo bezgrzeszne stworzenie ( $\gamma \varepsilon \dot{v} v \varepsilon \sigma \varsigma)$ i te same, podlegające cierpieniom, narodziny"32.

W cytowanym fragmencie zostają wymienione dwie kolejne konsekwencje grzechu: skażenie grzechem i śmiertelność.

5. Skażenie grzechem. Maksym Wyznawca twierdzi, iż według prawa zrodzenia nikt nie jest bezgrzeszny, gdyż wszyscy zostali poddani sposobowi zrodzenia nadanemu po stworzeniu z powodu grzechu. Wyznawca łączy fakt skażenia grzechem z uleganiem przez człowieka sferze irraacjonalnej33. Twierdzi, iż konsekwencją grzechu Adama jest prawo przyjemności, które zawładnęło człowiekiem osłabiając wolę i sferę racjonalną ${ }^{34}$. Po grzechu pierworodnym człowiek nie jest już nagi, traci prostotę, w której wystarcza mu do szczęścia Bóg. Szuka szczęścia w rozmaitych przyjemnościach zewnętrznych $^{35}$. Skłonność do złego zostaje bowiem zakorzeniona w ludzkiej naturze właśnie przez element zmysłowy ${ }^{36}$, który jest przekazywany poprzez ludzki sposób narodzin po grzechu Adama. Sfera zmysłowa nie tylko zostaje nazna-

${ }^{30}$ Por. D. Bathrellos, The temptation of Jesus Christ according to St Maximus the Confessor, StPatr 42 (2006) 45.

${ }^{31}$ Por. U. von Balthasar, Kosmiche Liturgie. Das Weltbild Maximus'des Bekenners, Einisiedeln 1961, 200.

${ }^{32}$ Maximus Confessor, Ambiguorum Liber 42, 7, PG 91, 1317A.

${ }^{33}$ Por. tamże 10, 28, PG 91, 1157A.

${ }^{34}$ Por. tenże, Quaestiones ad Thalassium 21, PG 90, 312C.

${ }^{35}$ Por. tenże, Ambiguorum Liber 45, PG 91, 1353D.

${ }^{36}$ Por. tenże, Quaestiones ad Thalassium 21, PG 90, 316C-D. 
czona skażeniem grzechu, ale i szczególnie narażona na ataki demonów ${ }^{37}$. Nie oznacza to jednak, że Maksym uznawał ludzką wolę po upadku za zupełnie złą i niezdolną do wyboru dobra. Jean Claude Larchet zaznacza jednak, że żaden inny Ojciec wschodni tak silnie jak Wyznawca nie akcentuje skażenia grzechem $^{38}$.

Z wszystkich wymienianych przez Maksyma konsekwencji grzechu tylko ta jedna ma charakter moralny i nie została przyjęta przez Chrystusa wraz z ludzką naturą. Chrzest daje wiernym łaskę bezgrzeszności ${ }^{39}$, jednak Maksym odnosi ją przede wszystkim do aspektu oczyszczenia i wzmocnienia woli, która została skażona grzechem, a nie do zniwelowania innych skutków grzechu, które zostały na trwałe wpisane w ludzką naturę i przyjęte przez samego Chrystusa.

6. Seksualność. Jak już wspominałam, po grzechu Adama zmienia się sposób przekazywania ludzkiej natury z czysto duchowego na płciowy ${ }^{40}$, czyjak to Maksym określa - zwierzęcy ${ }^{41}$. Wątek ten nie jest w myśli Ojców nowy. Maksym kontynuuje w swych poglądach przede wszystkim hipotezy Grzegorza z Nyssy ${ }^{42}$. Wskazuje na seksualny sposób rozmnażania się jako na drogę przekazywania śmiertelności oraz innych konsekwencji grzechu Adama ${ }^{43}$. Skutki grzechu pierwszego człowieka, nawet te, które same w sobie nie są grzeszne, przechodzą poprzez cielesny sposób narodzin na jego potomków ${ }^{44}$. Człowiek został przez upadek Adama skazany na to, aby rodzić się poprzez przyjemność i grzech. Nie chodzi tu jednak o uznanie stosunku seksualnego jako takiego za grzeszny. Maksym nie potępia ani ciała, które Adam miał od początku, ani seksualnego sposobu rozmnażania, który dopiero później został wpisany w prawo natury. W Ambigua 42 pisze dobitnie:

„Jeśli [...] uciekniecie się jednak do [argumentu] ostatecznego, stwierdzając, że nie godzi się, żeby to, co istnieje jako obraz Boga i boskie (co nazywacie duszą intelektualną), rozpoczynało istnienie w chwili wytrysku i nieczystej przyjemności, ale bardziej stosownie należałoby powiedzieć, że [dusza ta] jest wprowadzana wewnątrz [ciała] po czterdziestu dniach od poczęcia, to oczywiście oskarżacie Stwórcę natury i przez to popadacie w straszne niebezpieczeństwo ze względu na bluźnierstwo. Jeśli bowiem małżeństwo jest złe, to

\footnotetext{
${ }^{37}$ Por. tamże.

${ }^{38}$ Por. Larchet, Ancestral guilt according to St Maximus the Confessor, s. 42.

${ }^{39}$ Por. Maximus Confessor, Quaestiones ad Thalassium 61, PG 90, 636C.

${ }^{40}$ Por. tenże, Ambiguorum Liber 31, PG 91, 1276C.

${ }^{41}$ Por. tamże 10, 11, PG 91, 1121B.

${ }^{42}$ Por. Gregorius Nyssenus, De creatione hominis 17, PG 44, 187A-C, ŹMT 39, 97.

${ }^{43}$ Por. Maximus Confessor, Ambiguorum Liber 31, PG 91, 1276C; tamże 42, PG 91, 1316B-1317C; tenże, Questiones ad Thalassium 61, PG 90, 628A-C. 632D.

${ }^{44}$ Por. tenże, Questiones ad Thalassium 42, PG 90, 405D.
} 
oczywiście złe jest także naturalne prawo zrodzenia ( $\gamma \dot{\varepsilon} v v \eta \sigma ı)^{45}$. Jeśli zaś złe jest to naturalne prawo zrodzenia ( $\gamma \dot{\varepsilon} v v \eta \sigma \iota \varsigma)$, to oczywiście słusznie możemy

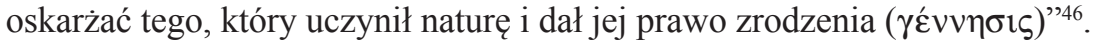

Seksualność rozumie więc Maksym jaką pewną funkcję, która w ludzkiej naturze pojawiał się dopiero po grzechu Adama i jest konieczna, aby ludzka natura mogła być przekazywana w swojej zmienionej pierwszym upadkiem kondycji.

7. Rozdarty wszechświat. Prócz wymienionych wcześniej konsekwencji grzechu, które dotknęły ludzką naturę, Maksym wskazuje też na skutki grzechu Adama dla całego wszechświata. Tak jak człowiek został oddzielony od wspólnoty ze Stwórcą, tak cały świat doświadcza rozdarcia. Maksym wskazuje pięć przestrzeni, w których uwidacznia się ten podział, czy może pięć podziałów: na mężczyznę i kobietę, stworzone i niestworzone, zmysłowe $i$ intelligibilne, ziemię i niebo, świat zamieszkały i raj ${ }^{47}$. Te podziały mają zniknąć na końcu czasów, a wszystkie elementy świata zostaną zjednoczone. Będzie to moment zniesienia wszelkich rozdarć i konfliktów (także tych wewnętrznych, które istnieją w człowieku) i zjednoczenia wszystkich stworzeń. Według Maksyma ten proces pojednania musi się rozpocząć od zniesienia fundamentalnego podziału między mężczyzną a kobietą. Oczywiście nawiązuje w ten sposób do cielesnego sposobu narodzin, który został wprowadzony po upadku Adama, a co za tym idzie, do faktu przekazywania konsekwencji grzechu.

Po grzechu, przez zmianę sposobu narodzin potomkowie Adama otrzymują ludzką naturę wraz z konsekwencjami grzechu. Wskutek upadku Adama ludzie rozmnażają się poprzez stosunek seksualny, tak samo jak zwierzęta. Kiedyś duchowemu, a teraz cielesnemu aktowi przekazywania życia towarzyszy przyjemność, co więcej, nie tylko towarzyszy, ale samo pragnienie przyjemności stanowi źródło grzechu. Maksym wskazuje na następstwa takiego stanu rzeczy: pożądliwość, cierpienie i ostatecznie śmierć. Ludzkie życie, a wraz z nim ludzka natura, zostają wpisane w zaklęty krąg przyjemności, cierpienia i śmierci. Maksym odwołuje się tu do prawa natury, które wydaje się utożsamiać z prawem grzechu. Dzieje się tak, ponieważ skłonność do cielesnej przyjemności, wpisana w sam akt prokreacji, zostaje przekazana przez rodziców wraz z innymi, następującymi po niej konsekwencjami pierwszego grzechu: cierpiętliwością, skażeniem grzechem przejawiającym się przede wszystkim osłabieniem woli, oraz śmiercią.

${ }^{45}$ Maksym w innych dziełach nie tylko nie deprecjonuje małżeństwa, ale nie uznaje wyższości dziewictwa.

${ }^{46}$ Maximus Confessor, Ambiguorum Liber 42, 6, PG 91, 1316D.

${ }^{47}$ Por. tamże 41, PG 91, 1308C-1309D. 


\section{ONTICAL CONSEQUENCES OF ADAM'S FALL - MAXIMUS THE CONFESSOR'S INTERPRETATION}

(Summary)

Maximus the Confessor points out that Adam's sin totally changed the mode of existence of human nature, which has since been proliferated via procreation involving sensual pleasure ( $\gamma \dot{\varepsilon} v v \eta \sigma i \varsigma)$. The focus on sensual pleasure is the primary consequence of Adam's sin. Sensual experiences are not sinful as such though they are particularly vulnerable to Satan's temptations. It is particularly dangerous when our will is weakened and inclined to choose evil. That is why Maximus links pleasure with suffering and death which are consequences of Adam's turning to pleasure - pleasure which at the same time caused his separation from God. Despite of passibility, corruption of will and death, which directly affect human nature, there are other consequences of Adam's sin that involve the universe as a whole. These are five divisions which destroy harmony in the cosmos: the division between man and woman, created and uncreated, sensual and intelligible, earth and heaven, settled world and paradise.

Słowa kluczowe: Maksym Wyznawca, grzech pierworodny, grzech Adama, natura ludzka, afekty.

Key words: Maximus the Confessor, original sin, Adam's sin, human nature, passibility. 